\title{
Reduced NFAT1 Protein Expression in Human Umbilical Cord Blood T Lymphocytes
}

\author{
By Suzanne Kadereit, Shaden F. Mohammad, Robin E. Miller, Kathleen Daum Woods, Chad D. Listrom, \\ Karen McKinnon, Alborz Alali, Linda S. Bos, Michelle L. Iacobucci, Michael R. Sramkoski, \\ J ames W. J acobberger, and Mary J . Laughlin
}

\begin{abstract}
Umbilical cord blood (UCB) stem cells from related and unrelated allogeneic donors have emerged as novel treatment for patients with hematologic malignancies. The incidence and severity of acute graft-versus-host disease (GVHD) after UCB transplantation compares favorably with that observed in recipients of matched unrelated donor allogeneic grafts, but remains a major cause of morbidity and mortality. It has been shown that stimulated lymphocytes from UCB have reduced production of cytokines including interferon- $\gamma$ (IFN- $\gamma$ ) and tumor necrosis factor- $\alpha$ (TNF- $\alpha$ ), which play a role in GVHD pathophysiology. We investigated the molecular mechanisms underlying this reduced cytokine production by analyzing expression of nuclear factor of activated T cells-1 (NFAT1) in UCB T cells. We detected no
\end{abstract}

A LLOGENEIC TRANSPLANTATION cures a significan number of patients with hematologic malignancies via immunologic mechanisms termed graft-versus-leukemia (GVL). ${ }^{1}$ The major obstacle to a successful outcome after transplantation is graft-versus-host disease (GVHD), resulting from donor T-cell alloreactivity against recipient major and minor histocompatibility antigens presented within the context of the major histocompatibility complex (MHC). ${ }^{2}$ Umbilical cord blood (UCB) from related and unrelated donors has recently emerged as a novel source of stem cells for patients requiring allogeneic transplantation. ${ }^{3-5}$ The incidence and severity of acute GVHD in UCB recipients compares favorably with that observed in recipients of matched unrelated donor grafts, but remains a major cause of morbidity and mortality. Of 562 patients transplanted with partially HLA mismatched UCB grafts, the majority of whom were less than age 18 years, $23 \%$ experienced severe acute GVHD (grade III to IV). ${ }^{5}$ In comparison, of 88 children transplanted with HLA-matched unrelated donor grafts, $37 \%$ experienced severe grade III to IV acute GVHD. ${ }^{6}$

$\mathrm{T}$ cells are known to play a central role in mediating GVHD. Allogeneic grafts depleted of $\mathrm{T}$ cells elicit reduced GVHD posttransplant. ${ }^{7,8}$ Donor $\mathrm{T}$ cells activated by recipient alloantigen produce Th1 type cytokines, thereby recruiting and activating other effector cells, which amplify donor T-cell alloreactivity and provoke tissue damage. Cytokines implicated directly in tissue damage during GVHD include tumor necrosis factor- $\alpha$ $(\mathrm{TNF}-\alpha)$ and interferon- $\gamma(\mathrm{IFN}-\gamma),{ }^{9,10}$

$\mathrm{T}$ cells in UCB are predominantly of naive phenotype $\left(\mathrm{CD} 45 \mathrm{RA}^{+}\right)$with reduced to absent $\mathrm{CD} 45 \mathrm{RO}^{+}$expression when compared with adult peripheral blood $\mathrm{T}$ cells. ${ }^{11}$ Upon primary stimulation, UCB T cells demonstrate activation marker expression equivalent to adult controls, as measured by $\mathrm{CD} 4 \mathrm{RA}^{+}$downregulation and upregulation of CD25, CD69, T-cell receptor (TCR), and p56 $6^{\text {lck }} \cdot{ }^{12-14}$ Moreover, upon primary TCR stimulation, UCB T cells and adult $\mathrm{T}$ cells proliferate to the same extent, as measured by thymidine incorporation. ${ }^{12}$ Importantly, however, certain effector functions of UCB T cells necessary to amplify T-cell responses to foreign antigens, are constitutive expression of NFAT1 protein in unstimulated UCB T cells compared with adult T cells. Moreover, although NFAT1 expression in UCB T cells was upregulated after prolonged (40 hours) T-cell stimulation, it was only partially upregulated when compared with adult controls. Our observation of minimal NFAT1 expression after stimulation correlated with reduced cytoplasmic IFN- $\gamma$ and TNF- $\alpha$ production in UCB T cells studied simultaneously. Reduced NFAT1 expression may blunt amplification of donor UCB T-cell alloresponsiveness against recipient antigens, thereby potentially limiting GVHD incidence and severity after allogeneic UCB transplantation.

reduced. For example, T-cell proliferation after secondary stimulation has been shown to be significantl reduced, and alloantigen-specifi cytotoxicity is decreased. ${ }^{15,16}$ Moreover, production of the cytokines interleukin-2 (IL-2), IL-4, IFN- $\gamma$, and TNF- $\alpha$ by activated UCB T cells is significantl reduced, when compared with adult T cells. ${ }^{11,17}$

The transcription of many cytokine genes and immunomodulatory molecules is regulated by nuclear factor of activated $\mathrm{T}$ cells-1 (NFAT1 or NFATp), a member of the NFAT family. ${ }^{18}$ NFAT1 is expressed constitutively at relatively high basal levels in unstimulated adult $\mathrm{T}$ cells and resides in latent form in the cytoplasm. ${ }^{19,20}$ NFAT1 mRNA expression in published reports is not significantl upregulated with short-term ( 2 to 3 hours) T-cell stimulation. ${ }^{20,21}$ However, a recent report describes expression of NFAT1 protein above basal constitutive levels measured in unstimulated $\mathrm{T}$ cells, after prolonged (10 to 30 days) T-cell priming. ${ }^{22}$ After TCR stimulation and consequent calcium influx constitutively expressed NFAT1 protein is activated through dephosphorylation by the phosphatase calci-

From the University Hospitals Ireland Comprehensive Cancer Center, Case Western Reserve University, Cleveland, $\mathrm{OH}$; and the Lineberger Comprehensive Cancer Center, University of North Carolina at Chapel Hill, Chapel Hill, NC.

Submitted March 17, 1999; accepted July 5, 1999.

Supported by Grant No. 6230-98 from The Leukemia Society of America. M.J.L. is a Stephen Birnbaum Translational Research Investigator of the Leukemia Society of America and Leukemia Scholar in Clinical Research.

Address reprint requests to Mary J. Laughlin, MD, Director, Allogeneic Transplant Program, Case Western Reserve University, University Hospitals Ireland Comprehensive Cancer Center, 11100 Euclid Ave, Cleveland, OH 44106-5065; e-mail: mjl13@po.cwru.edu.

The publication costs of this article were defrayed in part by page charge payment. This article must therefore be hereby marked "advertisement" in accordance with 18 U.S.C. section 1734 solely to indicate this fact. 
neurin. ${ }^{23}$ Dephosphorylation of NFAT1 correlates with its translocation to the nucleus and increase in DNA-binding activity. ${ }^{24,25}$

Cyclosporin A (CsA) and FK506, effective prophylactic and treatment agents against GVHD and powerful inhibitors of cytokine production, have been shown to inhibit calcineurin directly, as well as dephosphorylation and translocation of NFAT1. ${ }^{26-28}$ In addition, NFAT1 gene-deleted studies further establish the necessity of NFAT1 protein for the transcriptional upregulation of the IL-4, IFN- $\gamma$, granulocyte-macrophage colony-stimulating factor (GM-CSF), IL-13, TNF- $\alpha$, CD69, Fas Ligand (FasL), and CD40L genes. ${ }^{29}$ These observations together suggest a central role for NFAT1 in regulating cytokine production by activated T cells during GVHD.

Because little is known about the regulation of NFAT1 during GVHD or its activity in UCB T cells, we investigated NFAT1 expression in unstimulated and stimulated UCB T cells compared with adult $\mathrm{T}$ cells. We show here that NFAT1 protein expression is significantl reduced in unstimulated UCB T cells and is only partially expressed after prolonged (40 hours) primary TCR stimulation when compared with adult controls. These finding correlate with reduced IFN- $\gamma$ and TNF- $\alpha$ production by the same cells during prolonged primary TCR stimulation. Furthermore, we show that lack of NFAT1 expression in UCB T cells is not due to naive, CD45RA ${ }^{+}$phenotype. Reduced NFAT1 protein expression in UCB T cells may prevent amplificatio of activated donor UCB T-cell responses to recipient alloantigens posttransplant.

\section{MATERIALS AND METHODS}

Cells. Human UCB was collected into collection bags containing citrate dextrose (Allegiance, Deerfield IL) after vaginal deliveries or Cesarean sections of full-term pregnancies from healthy normal mothers, as approved by the Institutional Review Board at University Hospitals of Cleveland. Adult blood was collected into citrate dextrose, after informed consent of normal healthy adults. Mononuclear cells (MNC) were separated by gradient centrifugation on Histopaque-1077 (Sigma Chemical Co, St Louis, MO). Red blood cell contamination of $\mathrm{UCB}$ was reduced by gravity separation on $6 \%$ dextran (Sigma) before gradient centrifugation. MNC were used immediately fresh.

T-cell purification. $\mathrm{T}$ cells were purifie by negative depletion using a cocktail of monoclonal antibodies including: CD11b, CD16, CD19, and CD56 (PharMingen, San Diego, CA) followed by anti-IgG magnetic bead depletion, following manufacturer's instructions, with modification (Dynal, Lake Success, NY). Briefl, antibodies were added at $5 \mu \mathrm{g} / \mathrm{mL}$ each to $20 \times 10^{6}$ cells $/ \mathrm{mL}$ of $\mathrm{MNC}$ resuspended in RPMI $/ 10 \%$ fetal bovine serum (FBS) and incubated for 30 minutes on ice. Cells were washed twice and incubated in RPMI/10\% FBS at $20 \times$ $10^{6}$ cells $/ \mathrm{mL}$ with recommended amounts of magnetic beads. After purification T-cell purity was analyzed by flo cytometry and $\mathrm{CD}^{+}$ T-cell purity ranged between $90 \%$ to $97 \%$ of viable CD $45^{+}$cells. In studies of $\mathrm{CD} 45 \mathrm{RA} / \mathrm{RO}$ subsets, $\mathrm{CD}^{2} 5 \mathrm{RA}^{+} \mathrm{T}$ cells were further purifie from $\mathrm{T}$ cells by depleting with $10 \mu \mathrm{g} / \mathrm{mL}$ of anti-CD45RO monoclonal antibody in the same conditions as above (PharMingen). The resulting depleted population was single positive for CD45RA and purity ranged between $80 \%$ to $85 \%$ of viable $\mathrm{T}$ cells. The positively selected $\mathrm{CD} 4 \mathrm{RO}^{+}$population contained the $\mathrm{CD} 45 \mathrm{RO}$ single-positive population, as well as the double CD45RO/CD45RA-positive population.

Western blot analysis. Purifie T cells were lysed in $20 \mathrm{mmol} / \mathrm{L}$ Tris $\mathrm{pH} 7.6,50 \mathrm{mmol} / \mathrm{L} \mathrm{KCl}, 400 \mathrm{mmol} / \mathrm{L} \mathrm{NaCl}, 1 \mathrm{mmol} / \mathrm{L}$ EDTA, $1 \%$ Triton-X, 20\% glycerol, $1 \mathrm{mmol} / \mathrm{L}$ dithiothreitol (DTT), $0.5 \mathrm{mmol} / \mathrm{L}$ phenylmethylsulfonyl fluorid (PMSF), $1 \mu \mathrm{g} / \mathrm{mL}$ pepstatin, $2 \mu \mathrm{g} / \mathrm{mL}$ leupeptin, $2 \mu \mathrm{g} / \mathrm{mL}$ aprotinin, and $10 \mathrm{mmol} / \mathrm{L} \mathrm{Na}_{2} \mathrm{MoO}_{4}$. Protein extracts corresponding to $0.3 \times 10^{6}$ cells were loaded per lane and separated on 7\% sodium dodecyl sulfate-polyacrylamide gel electrophoresis (SDS-PAGE), transferred to polyvinylidene fluorid (PVDF) membrane (Millipore, Bedford, MA) and immunodetected with a mix of monoclonal antibodies directed against NFAT1 (Transduction Laboratories, Lexington, KY) and $\beta$-actin (Sigma). NFAT1 antibody was used at a dilution of $1 / 2,500$, the actin antibody at a dilution of $1 / 5,000$. The bands were visualized using enhanced chemiluminescence (Amersham, Buckinghamshire, UK) and band intensities were quantifie by densitometry scanning on Sci Scan 5000 (U.S. Biochemical, Cleveland, $\mathrm{OH})$. Band intensity was normalized for loading with the actin band, and NFAT1 band density was expressed in relative percentage of the strongest NFAT1 band on each gel. Purifie single-positive CD45RA ${ }^{+}$ $T$ cells were extracted after selection as outlined above and analyzed by Western blot. Positively selected $\mathrm{CD} 45 \mathrm{RO}^{+} \mathrm{T}$ cells were extracted directly on magnetic beads and analyzed in the same conditions as outlined above.

Primary T-cell stimulation. Each experiment was performed concomitantly on MNC from 2 UCB units and peripheral blood MNC from 2 adults. MNC were stimulated in bulk culture at concentration $2 \times 10^{6}$ cells $/ \mathrm{mL}$ with $2 \mu \mathrm{g} / \mathrm{mL}$ concanavalin A (Con A) (Sigma) in RPMI medium (GIBCO-BRL, Gaithersburg, MD) with 10\% FBS (GIBCO-BRL), $1 \mathrm{mmol} / \mathrm{L}$ sodium-pyruvate (GIBCO-BRL), $0.1 \mathrm{mmol} / \mathrm{L}$ nonessential amino acids (GIBCO-BRL), $10 \mathrm{mmol} / \mathrm{L}$ HEPES (GIBCO-BRL), and 58 $\mu \mathrm{mol} / \mathrm{L}$ 2-mercaptoethanol (Sigma) for 40 hours. T cells for Western blot analyses were isolated before stimulation and after stimulation and were lysed immediately.

Cytokine expression. Intracellular cytokine staining was performed concomitantly on the same MNC preparations using identical stimulation conditions as the Western blot analyses. Staining was performed using FastImmune (Becton Dickinson, San Jose, CA) according to the manufacturer's instructions with the following changes. MNC were stimulated at concentration $2 \times 10^{6}$ cells $/ \mathrm{mL}$ for 18 and 40 hours with 2 $\mu \mathrm{g} / \mathrm{mL}$ concanavalin A (Con A) (Sigma) in the presence of $5 \mu \mathrm{g} / \mathrm{mL}$ of Brefeldin A (BFA) (Becton Dickinson) for the fina 16 hours of stimulation. Red blood cells were lysed and MNC washed and permeabilized. A total of $0.5 \times 10^{6} \mathrm{MNC}$ were stained for 30 minutes at room temperature (RT) with the following antibodies: anti-IFN- $\gamma-$ fluorescei isothiocyanate (FITC) or anti-TNF- $\alpha$-FITC in the presence of anti-CD3-allophycocyanin (APC) and anti-CD69-phycoerythrin (PE) (Becton Dickinson). Cells were washed and fluorescenc was acquired immediately on Elite ESP flo cytometer (Coulter, Miami, FL). Data were analyzed with WinList (Verity Software House Inc, Topsham, $\mathrm{MN})$ and are plotted as T-cell-specifi $\left(\mathrm{CD}^{+}\right)$anti-cytokinereactivity (FITC-fluorescence versus surface CD69 reactivity.

\section{RESULTS}

Undetectable NFAT1 protein expression in unstimulated $U C B T$ cells. NFAT1 protein is expressed constitutively in human peripheral $\mathrm{T}$ cells and can readily be detected by Western blotting. ${ }^{20,30}$ We investigated NFAT1 expression in UCB T cells and compared this with adult controls. We prepared whole cell extracts from freshly purifie unstimulated T cells and analyzed NFAT1 protein expression by Western blotting. While NFAT1 protein was readily detectable in $3 \times 10^{5}$ unstimulated adult $\mathrm{T}$ cells (Fig 1A, lanes 7 to 9), we found no detectable NFAT1 expression in an equivalent number of unstimulated UCB T cells (Fig 1A, lanes 1 to 6), indicating reduced constitutive NFAT1 expression in unstimulated UCB T cells.

NFAT1 protein expression in CD45RA/RO T-cell subpopulations. T cells in UCB are predominantly of naive phenotype $\left(\mathrm{CD} 45 \mathrm{RA}^{+}\right)$with reduced to absent $\mathrm{CD}_{45 \mathrm{RO}^{+} \text {expressing } \mathrm{T}}$ cells, when compared with adult peripheral blood T cells. ${ }^{11}$ 


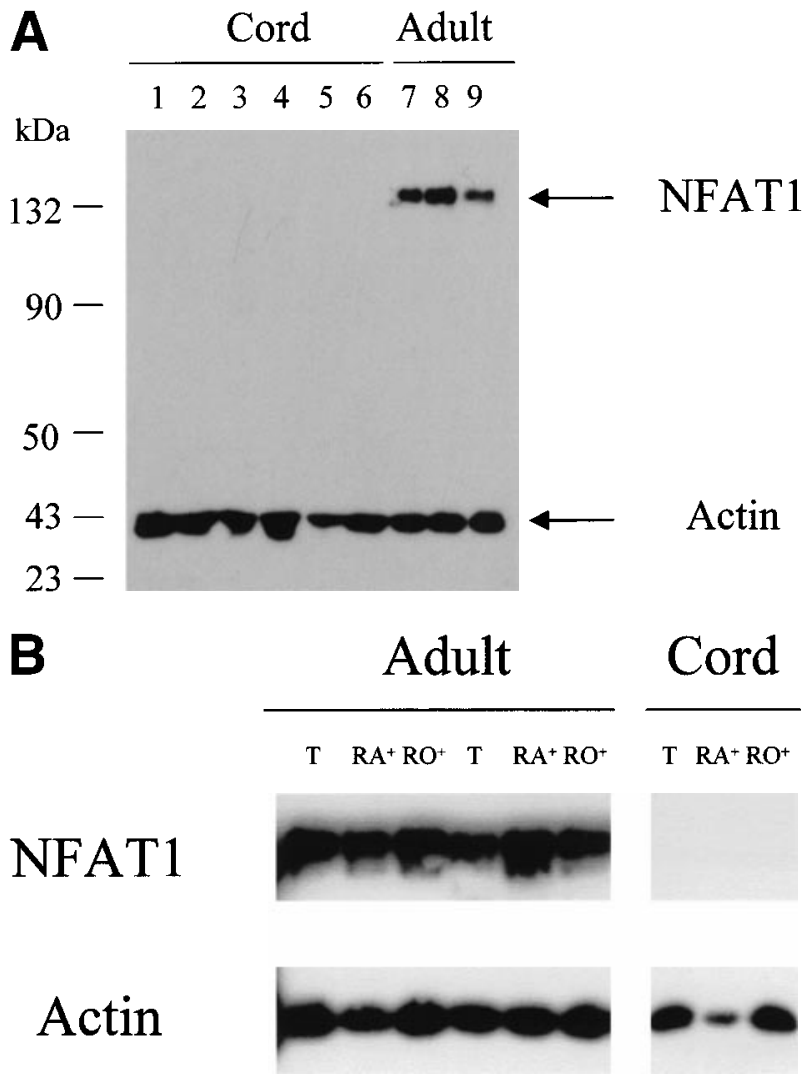

Fig 1. Undetectable NFAT1 protein expression in unstimulated UCB T cells. (A) T cells were purified from fresh MNC of 6 UCB units (lanes 1 through 6) and from 3 adult PBMC (lanes 7 through 9). Protein extracts equivalent to $3 \times 10^{5} \mathrm{~T}$ cells were loaded per lane and analyzed by Westem blotting with a combination of anti-NFAT1 and anti- $\beta$-actin antibodies. (B) $T$ cells were further separated into $\mathrm{CD}^{2} 5 \mathrm{RA}^{+}$and $\mathrm{CD}^{-} 5 \mathrm{RO}^{+}$expressing cells and protein extracts analyzed as above.

Reduced NFAT1 protein expression might therefore be attributable to the predominance of naive, $\mathrm{CD}_{45 \mathrm{RA}^{+}}$expressing $\mathrm{T}$ cells, rather than an intrinsic trait of UCB. NFAT1 protein expression was therefore measured by Western blot in CD45RA ${ }^{+}$ and $\mathrm{CD}_{45 \mathrm{RO}^{+}}$T-cell subpopulations from adult peripheral blood and UCB. In the adult, equivalent levels of NFAT1 protein were measured both in the CD45RA ${ }^{+}$and $\mathrm{CD}_{4} 4 \mathrm{RO}^{+}$ T-cell subsets (Fig 1B). In UCB T cells, no NFAT1 expression was detected in either $\mathrm{CD}_{45 \mathrm{RA}^{+}}$or $\mathrm{CD}_{45 \mathrm{RO}^{+}} \mathrm{T}$-cell subpopulations.

Reduced NFAT1 expression after prolonged UCB T-cell stimulation. Because we observed reduced NFAT1 protein expression in unstimulated UCB T cells, we investigated if we could upregulate NFAT1 protein expression by prolonged primary T-cell stimulation. Therefore, we stimulated MNC from freshly isolated UCB and adult peripheral blood for up to 40 hours with Con A, purifie the T cells at time points 18 hours and 40 hours and assessed NFAT1 expression by Western blot analysis.

Interestingly, we observed that in adult $\mathrm{T}$ cells, NFAT1 protein expression was upregulated 2 -fold after 40 hours of primary T-cell stimulation (Fig 2A and B). In UCB T cells, however, NFAT 1 expression remained deficien after 18 hours, with only $22 \%$ of the expression of NFAT 1 observed in adult at that time point, and was only partially upregulated after 40 hours of stimulation, averaging $45 \%$ of expression measured in adult $T$ cells.

Reduced cytoplasmic IFN- $\gamma$ and TNF- $\alpha$ expression in activated UCB T cells correlates with reduced NFAT1 expression. The transcription of numerous cytokines, including IFN- $\gamma$ and TNF- $\alpha$, is regulated by NFAT $1 .{ }^{18}$ In stimulated lymphocytes from NFAT1 gene-deleted mice, IFN- $\gamma$ and TNF- $\alpha$ expression has been shown to be reduced. ${ }^{29}$

Because we found deficien constitutive NFAT1 expression in unstimulated UCB T cells and only partial NFAT1 protein upregulation with prolonged TCR stimulation, we measured cytoplasmic expression of IFN- $\gamma$ and TNF- $\alpha$ in UCB T cells at time points 18 hours and 40 hours of Con A stimulation using the same UCB and adult MNC as for our Western blot analyses. While performing the Con A stimulation experiments for NFAT1 Western blotting described above, MNC from the same UCB and adult peripheral bloods, stimulated concomitantly in identical study conditions, were analyzed for intracellular cytokine expression. Intracellular cytokine expression was analyzed using 3-color flo cytometric analysis with directly conjugated monoclonal antibodies specifi for CD3, the early activation marker CD69, and the cytokines IFN- $\gamma$ and TNF- $\alpha$. Cytoplasmic IFN- $\gamma$ and TNF- $\alpha$ expression were then measured in gated activated, $\mathrm{CD} 69$ expressing $\mathrm{CD}^{+} \mathrm{T}$ cells.

In accordance with the reduced NFAT1 expression measured by Western blot in UCB T cells, we found a reduced number of IFN- $\gamma$ and TNF- $\alpha$ producing cells in UCB T cells at the time point 18 hours of Con A stimulation (Fig 3, Table 1). While on average $3.5 \%$ of adult activated $\mathrm{T}$ cells expressed IFN- $\gamma$ and $5.8 \%$ expressed TNF- $\alpha$ after 18 hours of prolonged T-cell stimulation, we found on average only $1.5 \%$ of activated UCB T cells expressing IFN- $\gamma$ and $2.7 \% \mathrm{CD}^{+} / \mathrm{CD} 69^{+} \mathrm{UCB} \mathrm{T}$ cells expressing cytoplasmic TNF- $\alpha$. After 40 hours of Con A stimulation, at the time point when NFAT1 protein became detectable by Western blotting in UCB T cells and doubled in adult controls, TNF- $\alpha$ expressing T cells in UCB increased to $6.3 \%$ and almost doubled in adult controls to $10.8 \%$. Further increases in IFN- $\gamma$ producing $\mathrm{T}$ cells in either UCB or adult controls were not observed between 18 hours and 40 hours of Con A stimulation.

\section{DISCUSSION}

Transcription factors of the NFAT family play a major role in the regulation of cytokine genes and other effector molecules modulated during immune responses. While putative binding sites for NFAT1 have been described on the regulatory elements of many genes, only recent in vivo data from NFAT1 genedeleted mice confirme the crucial role of NFAT1 in the transcription of the IL- 4 , IFN- $\gamma$, GM-CSF, IL-13, TNF- $\alpha$, CD69, FasL, and CD40L genes. ${ }^{29}$

The surface phenotype and functional deficiencie described for murine NFAT1 gene-deleted lymphocytes resembles that of human UCB lymphocytes. Activated lymphocytes from UCB produce reduced amounts of IL- 4 , IFN- $\gamma$, TNF- $\alpha$, GM-CSF, and have reduced surface expression of CD40L.411,31,32 These 
A Cord Blood

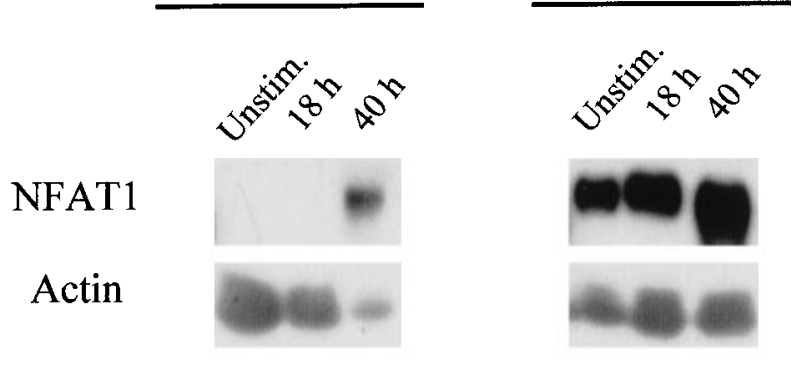

NFAT1

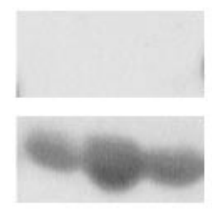

Actin
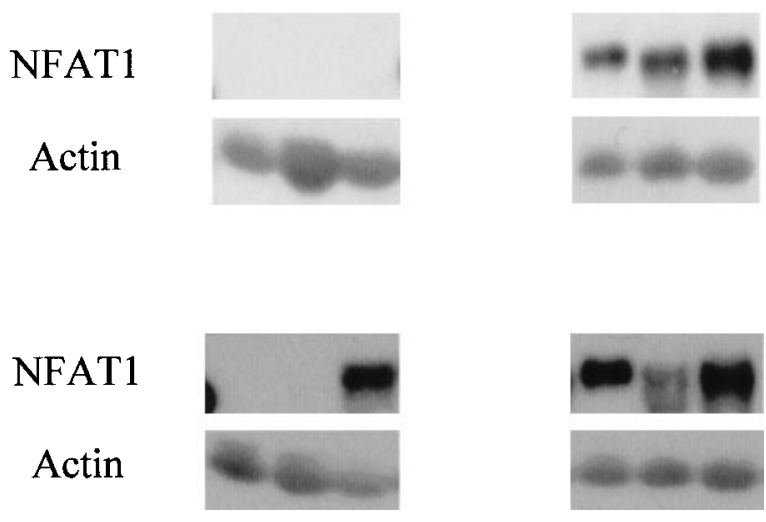

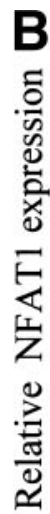

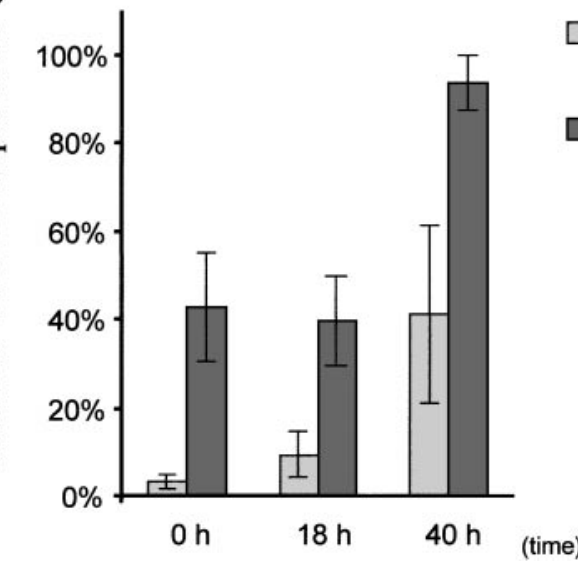

Fig 2. Reduced upregulation of NFAT1 protein in UCB T cells during primary stimulation. (A) MNC from 2 UCB units and 2 adults were stimulated in parallel with Con A for $\mathbf{4 0}$ hours. At $\mathbf{0}$ hour (unstim), 18 hours, and $\mathbf{4 0}$ hours of stimulation, $\mathrm{T}$ cells were purified and extracted and NFAT1 protein expression analyzed by Westem blotting. The results shown are representative of 5 independent experiments, comparing in each experiment 2 UCB and 2 adult controls analyzed together and run on the same gel. (B) Graphic representation of the mean $( \pm S E)$ of the quantification of relative NFAT1 expression after stimulation with Con A. Gel loading was normalized for each lane with the actin band and the intensity of each NFAT1 band was calculated as relative percentage of the most intense NFAT1 band on each gel. The most intensive band was set arbitrarily at $100 \%$ and relative percentages were then averaged and graphed. properties suggested reduced NFAT1 function in UCB lymphocytes. We therefore analyzed NFAT1 protein expression in UCB $\mathrm{T}$ cells and compared it with expression in adult $\mathrm{T}$ cells. We show herein, that in freshly isolated unstimulated UCB T cells, constitutive NFAT1 protein expression is undetectable, as measured by Western blotting, in conditions where it is readily detectable in adult $T$ cells.

As $\mathrm{T}$ cells in $\mathrm{UCB}$ are predominantly of naive phenotype $\left(\mathrm{CD} 45 \mathrm{RA}^{+}\right)$with reduced to absent $\mathrm{CD} 45 \mathrm{RO}^{+}$expression when compared with adult peripheral blood $\mathrm{T}$ cells,,${ }^{11}$ one might hypothesize that reduced NFAT1 protein expression is attributable to the naive, $\mathrm{CD}_{45 \mathrm{RA}^{+}}$phenotype of $\mathrm{T}$ cells in $\mathrm{UCB}$, rather than an intrinsic trait of UCB $\mathrm{T}$ cells. However, our analysis of NFAT1 protein expression by Western blot in $\mathrm{CD}_{45 \mathrm{RA}^{+}}$and $\mathrm{CD} 45 \mathrm{RO}^{+}$T-cell subpopulations from adult and UCB does not support this hypothesis. Rather, we measured similar levels of NFAT1 expression in both adult CD45RA ${ }^{+}$and $\mathrm{CD}_{45 \mathrm{RO}^{+}}$subpopulations and could not detect NFAT1 in either subpopulation in UCB. These finding strongly suggest that the reduced constitutive expression of NFAT1 we observe in unstimulated UCB T cells is an intrinsic property of cord blood.

Upregulation of NFAT1 protein during primary stimulation of adult $\mathrm{T}$ cells has not been described. However, a recent report described upregulation of NFAT1 protein levels after 10 to 30 days of priming of peripheral adult T cells. ${ }^{22}$ Our data demonstrates that in adult T cells, NFAT1 is upregulated 2-fold after 40 hours of stimulation. Importantly, however, our results show that after 18 hours of primary T-cell stimulation, there is still deficien NFAT1 expression seen in UCB T cells. Furthermore, after 40 hours of stimulation, NFAT1 expression remains significantl reduced in UCB T cells, averaging only $45 \%$ of adult expression.

Interestingly, our studies using concomitant measurement of NFAT1 by Western blotting with cytoplasmic expression of IFN- $\gamma$ and TNF- $\alpha$ show that upregulation of NFAT1 in adult T cells after 40 hours of stimulation correlates with the late upregulation of cytoplasmic TNF- $\alpha$ expression. Furthermore, in agreement with reduced NFAT1 protein levels expressed by UCB T cells, we detected reduced TNF- $\alpha$ producing $\mathrm{T}$ cells in UCB at 18 hours time point of primary T-cell stimulation. After 40 hours of T-cell stimulation, when NFAT1 expression in UCB $\mathrm{T}$ cells is upregulated to $45 \%$ of that measured in adult T cells, TNF- $\alpha$ production is noted to increase to almost one half that of adult controls. IFN- $\gamma$ expression increased above baseline expression after 18 hours of Con A stimulation, but did not increase further after 40 hours of stimulation in UCB and adult $\mathrm{T}$ cells, suggesting dependence on transcription factors other than NFAT1 at this later time point. It is interesting to note here that upregulation of IFN- $\gamma$ mRNA in NFAT1 gene-deleted lymphocytes has been shown to be less deficien than upregulation of TNF- $\alpha$ mRNA. ${ }^{29}$

One might argue that reduced IFN- $\gamma$ and TNF- $\alpha$ production could be attributable to excess Th2 type cytokine production by UCB T cells. However, previous reports point to reduced rather than increased Th2 type cytokine production by UCB T cells. ${ }^{11,17}$ This phenotype of reduced expression of Th2 cytokines is also observed in murine NFAT1 gene-deleted lymphocytes. $^{29}$ In this model, NFAT1 protein expression has been 
A Unstimulated
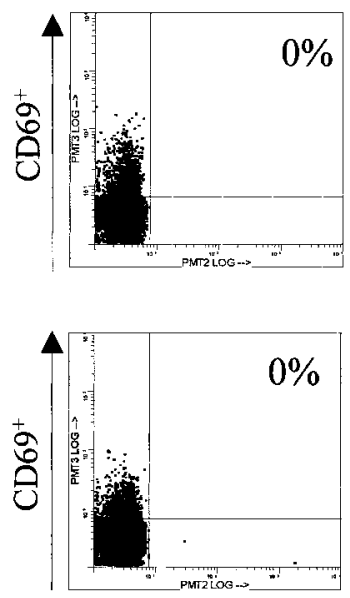

$18 \mathrm{~h}$
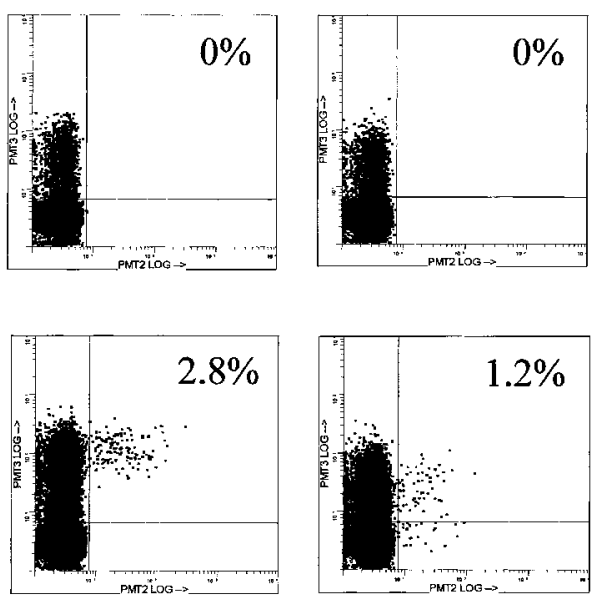

$40 \mathrm{~h}$

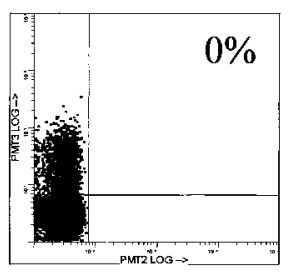

Cord

Adult

IFN- $\gamma$

Fig 3. Cytoplasmic expression of IFN- $\gamma$ and TNF- $\alpha$ by UCB and adult $T$ cells. Intracellular staining was performed in parallel and on the same MNC during the primary Con A stimulation experiments for NFAT1 analysis by Westem blotting. MNC from UCB or adult peripheral blood were left unstimulated or stimulated using Con A for $\mathbf{4 0}$ hours in identical conditions and analyzed for intracellular expression of cytokines by flow cytometry. At 0 hour (unstim), 18 hours, and 40 hours of stimulation, $\mathrm{CD3}^{+}$ cells were gated and intracellular cytokine expression in gated cells was plotted versus CD69 expression. Numbers in histograms indicate the percentage of $\mathrm{CD}^{+} / \mathrm{CD}^{2} 9^{+}$cells expressing the cytokine. (A) Intracellular staining for IFN- $\gamma$. (B) Intracellular staining for TNF- $\alpha$.
B Unstimulated
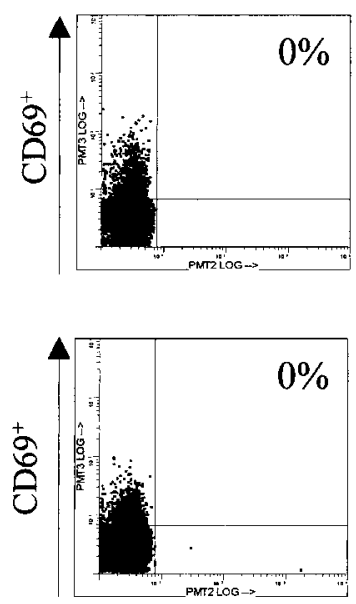

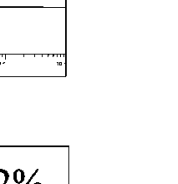


of clinical GVHD. Accordingly, levels of these cytokines are significantl increased in allogeneic recipients during GVHD reactions. ${ }^{9,33,34}$ Moreover, clinical trials show that administration of anti-TNF- $\alpha$ antibodies is effective for prophylaxis and attenuation of GVHD in allogeneic bone marrow transplant recipients. ${ }^{35,36}$ Likewise, it has been shown that administration of a xanthine derivative pentoxifylline, capable of downregulating TNF- $\alpha$ production, reduced GVHD incidence and severity in bone marrow transplant recipients. ${ }^{37}$ IFN- $\gamma$ also synergizes with lipopolysaccaride (LPS), released upon tissue damage in allogeneic recipients receiving ablative chemoradiotherapy conditioning regimens, to augment $\mathrm{TNF}-\alpha$ production during the early posttransplant time period. ${ }^{38,39}$

In addition to affording a possible new strategy for specifi immune modulation, our results suggest a potential molecular mechanism underlying the reported reduced incidence and severity of GVHD observed in allogeneic UCB transplant recipients. Whether there is a possible link between NFAT1 protein expression and incidence and severity of GVHD in recipients of allogeneic UCB is currently under active investigation.

\section{ACKNOWLEDGMENT}

The authors thank the Labor and Delivery staff of McDonald's Women Hospital for their enthusiastic support.

\section{REFERENCES}

1. Fefer A, Sullivan KM, Weiden P, Buckner CD, Schoch G, Storb R, Thomas ED: Graft versus leukemia effect in man: The relapse rate of acute leukemia is lower after allogeneic than after syngeneic marrow transplantation. Prog Clin Biol Res 244:401, 1987

2. Goulmy E: Human minor histocompatibility antigens. Curr Opin Immunol 8:75, 1996

3. Kurtzberg J, Laughlin M, Graham ML, Smith C, Olson JF, Halperin EC, Ciocci G, Carrier C, Stevens CE, Rubinstein P: Placental blood as a source of hematopoietic stem cells for transplantation into unrelated recipients. N Engl J Med 335:157, 1996

4. Cairo MS, Wagner JE: Placental and/or umbilical cord blood: An alternative source of hematopoietic stem cells for transplantation. Blood 90:4665, 1997

5. Rubinstein P, Carrier C, Scaradavou A, Kurtzberg J, Adamson J, Migliaccio AR, Berkowitz RL, Cabbad M, Dobrila NL, Taylor PE, Rosenfiel RE, Stevens CE: Outcomes among 562 recipients of placental-blood transplants from unrelated donors. N Engl J Med 339:1565, 1998

6. Balduzzi A, Gooley T, Anasetti C, Sanders J, Martin P, Petersdorf E, Appelbaum F, Buckner C, Matthews D, Storb R, Sullivan K, Hansen J: Unrelated donor marrow transplantation in children. Blood 86:3247, 1995

7. Soiffer RJ, Ritz J: Selective T cell depletion of donor allogeneic marrow with anti-CD6 monoclonal antibody: Rationale and results. Bone Marrow Transplant 12:S7, 1993

8. Verdonck LF, Dekker AW, de Gast GC, van Kempen ML, Lokhorst HM, Nieuwenhuis HK: Allogeneic bone marrow transplantation with a fixe low number of $\mathrm{T}$ cells in the marrow graft. Blood 83:3090, 1994

9. Holler E, Kolb HJ, Hintermeier-Knabe R, Mittermuller J, Thierfelder S, Kaul M, Willmanns W: Role of tumor necrosis factor alpha in acute graft-versus-host disease and complications following allogeneic bone marrow transplantation. Transplant Proc 25:1234, 1993

10. Klingebiel T, Schlegel PG: GVHD: Overview on pathophysiology, incidence, clinical and biological features. Bone Marrow Transplant 21:S45, 1998
11. Chalmers IM, Janossy G, Contreras M, Navarrete C: Intracellular cytokine profil of cord and adult blood lymphocytes. Blood 92:11, 1998

12. Risdon G, Gaddy J, Stehman FB, Broxmeyer HE: Proliferative and cytotoxic responses of human cord blood $\mathrm{T}$ lymphocytes following allogeneic stimulation. Cell Immunol 154:14, 1994

13. Pirenne-Ansart H, Paillard F, De Groote D, Eljaafari A, Le Gac S, Blot P, Franchimont P, Vaquero C, Sterkers G: Defective cytokine expression but adult-type T-cell receptor, CD8, and p561ck modulation in CD3- or CD2-activated T cells from neonates. Pediatr Res 37:64, 1995

14. Zola H, Ridings J, Elliott S, Nobbs S, Weedon H, Wheatland L, Haslam R, Roberton D, Macardle PJ: Interleukin 2 receptor regulation and IL-2 function in the human infant. Hum Immunol 59:615, 1998

15. Risdon G, Gaddy J, Horie M, Broxmeyer HE: Alloantigen priming induces a state of unresponsiveness in human umbilical cord blood T cells. Proc Natl Acad Sci USA 92:2413, 1995

16. Porcu P, Gaddy J, Broxmeyer HE: Alloantigen-induced unresponsiveness in cord blood T lymphocytes is associated with defective activation of Ras. Proc Natl Acad Sci USA 95:4538, 1998

17. Andersson U, Andersson J, Lindfors A, Wagner K, Moller G, Heusser CH: Simultaneous production of interleukin 2, interleukin 4 and interferon-gamma by activated human blood lymphocytes. Eur J Immunol 20:1591, 1990

18. Rao A, Luo C, Hogan PG: Transcription factors of the NFAT family: Regulation and function. Annu Rev Immunol 15:707, 1997

19. McCaffrey PG, Luo C, Kerppola TK, Jain J, Badalian TM, Ho AM, Burgeon E, Lane WS, Lambert JN, Curran T, Verdine GL, Rao A, Hogan PG: Isolation of the cyclosporin-sensitive $\mathrm{T}$ cell transcription factor NFATp. Science 262:750, 1993

20. Lyakh L, Ghosh P, Rice NR: Expression of NFAT-family proteins in normal human T cells. Mol Cell Biol 17:2475, 1997

21. Northrop JP, Ho SN, Chen L, Thomas DJ, Timmerman LA, Nolan GP, Admon A, Crabtree GR: NF-AT components defin a family of transcription factors targeted in T-cell activation. Nature 369:497, 1994

22. Cron R, Bort S, Wang Y, Brunvand M, Lewis D: T cell priming enhances IL-4 gene expression by increasing nuclear factor of activated T cells. J Immunol 162:860, 1999

23. Loh C, Shaw KT, Carew J, Viola JP, Luo C, Perrino BA, Rao A: Calcineurin binds the transcription factor NFAT1 and reversibly regulates its activity. J Biol Chem 271:10884, 1996

24. Park J, Yaseen NR, Hogan PG, Rao A, Sharma S: Phosphorylation of the transcription factor NFATp inhibits its DNA binding activity in cyclosporin A-treated human B and T cells. J Biol Chem 270:20653, 1995

25. Ruff VA, Leach KL: Direct demonstration of NFATp dephosphorylation and nuclear localization in activated HT-2 cells using a specifi NFATp polyclonal antibody. J Biol Chem 270:22602, 1995

26. Flanagan WM, Corthesy B, Bram RJ, Crabtree GR: Nuclear association of a T-cell transcription factor blocked by FK-506 and cyclosporin A. Nature 352:803, 1991

27. Zheng XX, Strom TB, Steele AW: Quantitative comparison of rapamycin and cyclosporine effects on cytokine gene expression studied by reverse transcriptase-competitive polymerase chain reaction. Transplantation 58:87, 1994

28. Beals CR, Clipstone NA, Ho SN, Crabtree GR: Nuclear localization of NF-ATc by a calcineurin-dependent, cyclosporine-sensitive intramolecular interaction. Genes Dev 11:824, 1997

29. Hodge MR, Ranger AM, de la Brousse FC, Hoey T, Grusby MJ, Glimcher LH: Hyperproliferation and dysregulation of IL-4 expression in NF-ATp-deficien mice. Immunity 4:397, 1996

30. Shaw KT, Ho AM, Raghavan A, Kim J, Jain J, Park J, Sharma S, Rao A, Hogan PG: Immunosuppressive drugs prevent a rapid dephos- 
phorylation of transcription factor NFAT1 in stimulated immune cells. Proc Natl Acad Sci USA 92:11205, 1995

31. Harris DT, LoCascio J, Besencon FJ: Analysis of the alloreactive capacity of human umbilical cord blood: Implications for graft-versushost disease. Bone Marrow Transplant 14:545, 1994

32. Durandy A, De Saint Basile G, Lisowska-Grospierre B, Gauchat JF, Forveille M, Kroczek RA, Bonnefoy JY, Fischer A: Undetectable CD40 ligand expression on T cells and low B cell responses to CD40 binding agonists in human newborns. J Immunol 154:1560, 1995

33. Roy J, Blazar BR, Ochs L, Weisdorf DJ: The tissue expression of cytokines in human acute cutaneous graft-versus-host disease. Transplantation 60:343, 1995

34. Niederwieser D, Herold M, Woloszczuk W, Aulitzky W, Meister B, Tilg H, Gastl G, Bowden R, Huber C: Endogenous IFN-gamma during human bone marrow transplantation. Analysis of serum levels of interferon and interferon-dependent secondary messages. Transplantation 50:620, 1990

35. Herve $\mathrm{P}$, Flesch $\mathrm{M}$, Tiberghien $\mathrm{P}$, Wijdenes $\mathrm{J}$, Racadot $\mathrm{E}$, Bordigoni P, Plouvier E, Stephan JL, Bourdeau H, Holler E, Lioure B, Roche C, Vilmer E, Domeocq F, Kuentz M, Cahn JY: Phase I-II trial of a monoclonal anti-tumor necrosis factor alpha antibody for the treatment of refractory severe acute graft-versus-host disease. Blood 79:3362, 1992

36. Holler E, Kolb HJ, Mittermuller J, Kaul M, Ledderose G, Duell T, Seeber B, Schleuning M, Hintermeier-Knabe R, Ertl B, Kempeni J, Wilmanns W: Modulation of acute graft-versus-host-disease after allogeneic bone marrow transplantation by tumor necrosis factor alpha (TNF alpha) release in the course of pretransplant conditioning: Role of conditioning regimens and prophylactic application of a monoclonal antibody neutralizing human TNF alpha (MAK 195F). Blood 86:890, 1995

37. Bianco JA, Appelbaum FR, Nemunaitis J, Almgren J, Andrews F, Kettner P, Shields A, Singer JW: Phase I-II trial of pentoxifylline for the prevention of transplant-related toxicities following bone marrow transplantation. Blood 78:1205, 1991

38. Gifford GE, Lohmann-Matthes ML: Gamma interferon priming of mouse and human macrophages for induction of tumor necrosis factor production by bacterial lipopolysaccharide. J Natl Cancer Inst 78:121, 1987

39. Vora A, Monaghan J, Nuttall P, Crowther D: Cytokine-mediated nitric oxide release - a common cytotoxic pathway in host-versus-graft and graft-versus-host reactions. Bone Marrow Transplant 20:385, 1997 